Supplement of Biogeosciences, 15, 1863-1878, 2018

https://doi.org/10.5194/bg-15-1863-2018-supplement

(C) Author(s) 2018. This work is distributed under

the Creative Commons Attribution 4.0 License.

(c) (1)

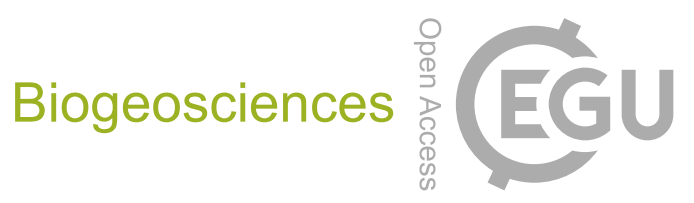

Supplement of

\title{
Carbon amendment stimulates benthic nitrogen cycling during the bioremediation of particulate aquaculture waste
}

\section{Georgina Robinson et al.}

Correspondence to: Georgina Robinson (georgina.robinson@sams.ac.uk)

The copyright of individual parts of the supplement might differ from the CC BY 4.0 License. 
2 Table S1. Mean ( \pm standard error) ambient environmental (light, temperature, salinity), nutrient and gas 3 concentrations recorded in the incubation chambers on day -1 at the start of the light and dark 4 incubations.

\begin{tabular}{lrrrrrrr}
\hline & \multicolumn{3}{c}{ Light } & \multicolumn{4}{c}{ Dark } \\
\hline & Mean & & \multicolumn{1}{c}{ SE } & Mean & & SE \\
\hline Light (lux) & 132.08 & \pm & 9.63 & & \pm & - \\
Temperature $\left({ }^{\circ} \mathrm{C}\right)$ & 29.34 & \pm & 0.06 & 28.62 & \pm & 0.04 \\
Salinity $\left(\mathrm{mg} \mathrm{L}^{-1}\right)$ & 35.00 & \pm & 0.00 & 35.00 & \pm & 0.00 \\
$\mathrm{pH}$ & 8.03 & \pm & 0.00 & 8.24 & \pm & 0.00 \\
Ammonia (uM) & 2.93 & \pm & 0.13 & 2.58 & \pm & 0.23 \\
Nitrite (uM) & 0.29 & \pm & 0.08 & 0.58 & \pm & 0.09 \\
Nitrate (uM) & 6.98 & \pm & 0.56 & 7.46 & \pm & 0.51 \\
Phosphate (uM) & 0.57 & \pm & 0.03 & 0.47 & \pm & 0.01 \\
Dissolved inorganic carbon $(\mathrm{uM})$ & $2,717.56$ & \pm & 19.90 & $2,357.03$ & \pm & 27.46 \\
Dissolved oxygen (uM) & 162.60 & \pm & 1.06 & 166.28 & \pm & 1.04 \\
Nitrogen gas (uM) & - & \pm & - & 387.42 & \pm & 1.50 \\
\hline
\end{tabular}


6 Table S2. Overview of the pathways modules and reference profiles within nitrogen metabolism used 7 to calculate the predicted relative abundance of genes within each pathway. All data was extracted from 8 the Kyoto Encyclopaedia for Genes and Genomes (KEGG) database www.genome.jp/kegg/.

\begin{tabular}{|c|c|c|c|}
\hline Pathway & Overview & Module & $\begin{array}{l}\text { KEGG Ortholog reference profile } \\
\text { (KO) }\end{array}$ \\
\hline Nitrogen fixation & Nitrogen $=>$ ammonia & M00175 & $\begin{array}{l}\mathrm{K} 02588+\mathrm{K} 02586+\mathrm{K} 02591- \\
\mathrm{K} 00531\end{array}$ \\
\hline Nitrification & Ammonia $=>$ nitrite & M00528 & K10944+K10945+K10946 K10535 \\
\hline Denitrification & Nitrate $=>$ nitrogen & M00529 & $\begin{array}{l}(\mathrm{K} 00370+\mathrm{K} 00371+\mathrm{K} 00374+\mathrm{K} 00373, \\
\mathrm{K} 02567+\mathrm{K} 02568)(\mathrm{K} 00368, \mathrm{~K} 15864) \\
(\mathrm{K} 04561+\mathrm{K} 02305, \mathrm{~K} 15877) \mathrm{K} 00376\end{array}$ \\
\hline $\begin{array}{l}\text { Dissimilatory } \\
\text { nitrate reduction }\end{array}$ & Nitrate $=>$ ammonia & M00530 & $\begin{array}{l}(\mathrm{K} 00370+\mathrm{K} 00371+\mathrm{K} 00374+\mathrm{K} 00373, \\
\mathrm{K} 02567+\mathrm{K} 02568) \\
(\mathrm{K} 00362+\mathrm{K} 00363, \mathrm{~K} 03385+\mathrm{K} 15876)\end{array}$ \\
\hline $\begin{array}{l}\text { Assimilatory nitrate } \\
\text { reduction }\end{array}$ & Nitrate $=>$ ammonia & M00531 & $\begin{array}{l}(\mathrm{K} 00367, \mathrm{~K} 10534, \mathrm{~K} 00372-\mathrm{K} 00360) \\
(\mathrm{K} 00366, \mathrm{~K} 17877)\end{array}$ \\
\hline $\begin{array}{l}\text { Complete } \\
\text { nitrification }\end{array}$ & $\begin{array}{l}\text { Ammonia }=>\text { nitrite }=> \\
\text { nitrate }\end{array}$ & M00804 & $\begin{array}{l}\text { K10944+K10945+K10946 } \\
\text { K10535 K00370+K00371 }\end{array}$ \\
\hline
\end{tabular}


11 Fig. S1. Mean ( \pm standard error) net fluxes (in $\mu \mathrm{mol} \mathrm{m}^{-2} \mathrm{~h}^{-1} ; \mathrm{n}=5$ ) of: a) dissolved oxygen 12 (DO); b) dissolved inorganic carbon (DIC); c) dinitrogen gas $\left(\mathrm{N}_{2}\right)$; and, d) gross primary 13 production (GPP) in incubation chambers under light and dark conditions on day -1, prior to 14 the addition of sea cucumbers and aquaculture waste with $(+\mathrm{C})$ or without $(-\mathrm{C})$ carbon.

a)

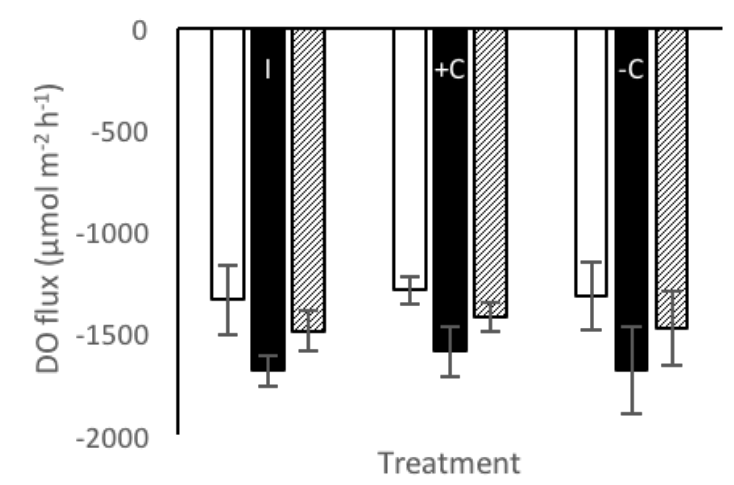

c)

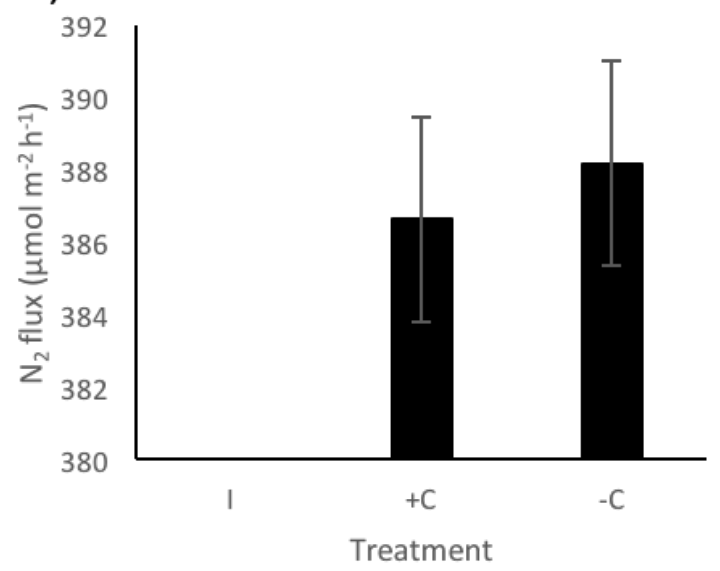

b)

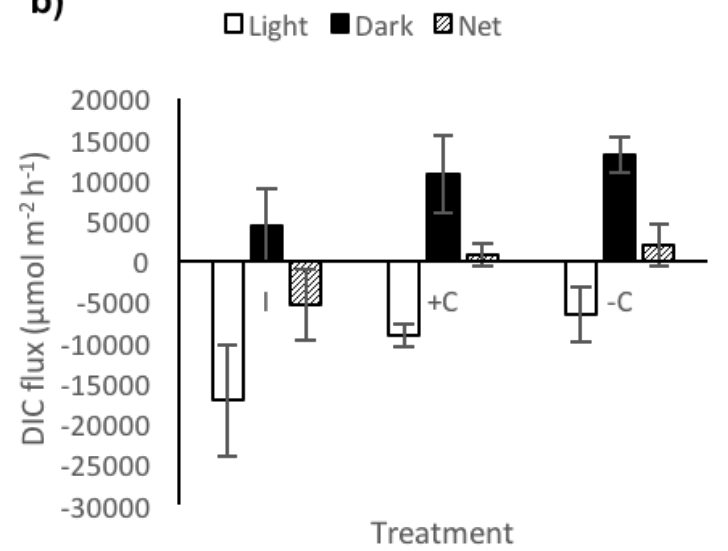

d)

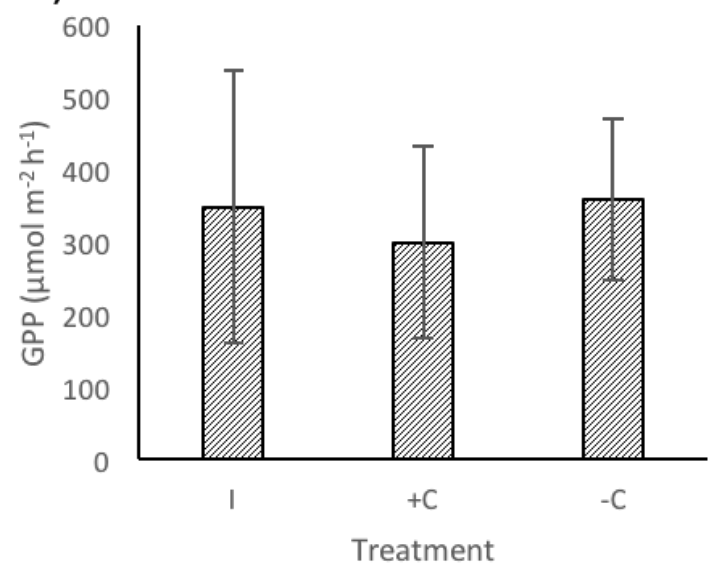


17 Fig. S2. Mean ( \pm standard error) benthic light, dark and net fluxes (in $\mu \mathrm{mol} \mathrm{m}^{-2} \mathrm{~h}^{-1} ; \mathrm{n}=5$ ) of: 18 a) phosphate $\left(\mathrm{PO}_{4}{ }^{3-}\right)$; b) ammonium $\left(\mathrm{NH}_{4}{ }^{+}\right)$; c) nitrite $\left(\mathrm{NO}_{2}^{-}\right)$; and d) nitrate and nitrite $\left(\mathrm{NO}_{\mathrm{x}}\right)$ 19 in incubation chambers under light and dark conditions on day -1 , prior to the addition of sea 20 cucumbers and aquaculture waste with $(+\mathrm{C})$ or without $(-\mathrm{C})$ carbon.
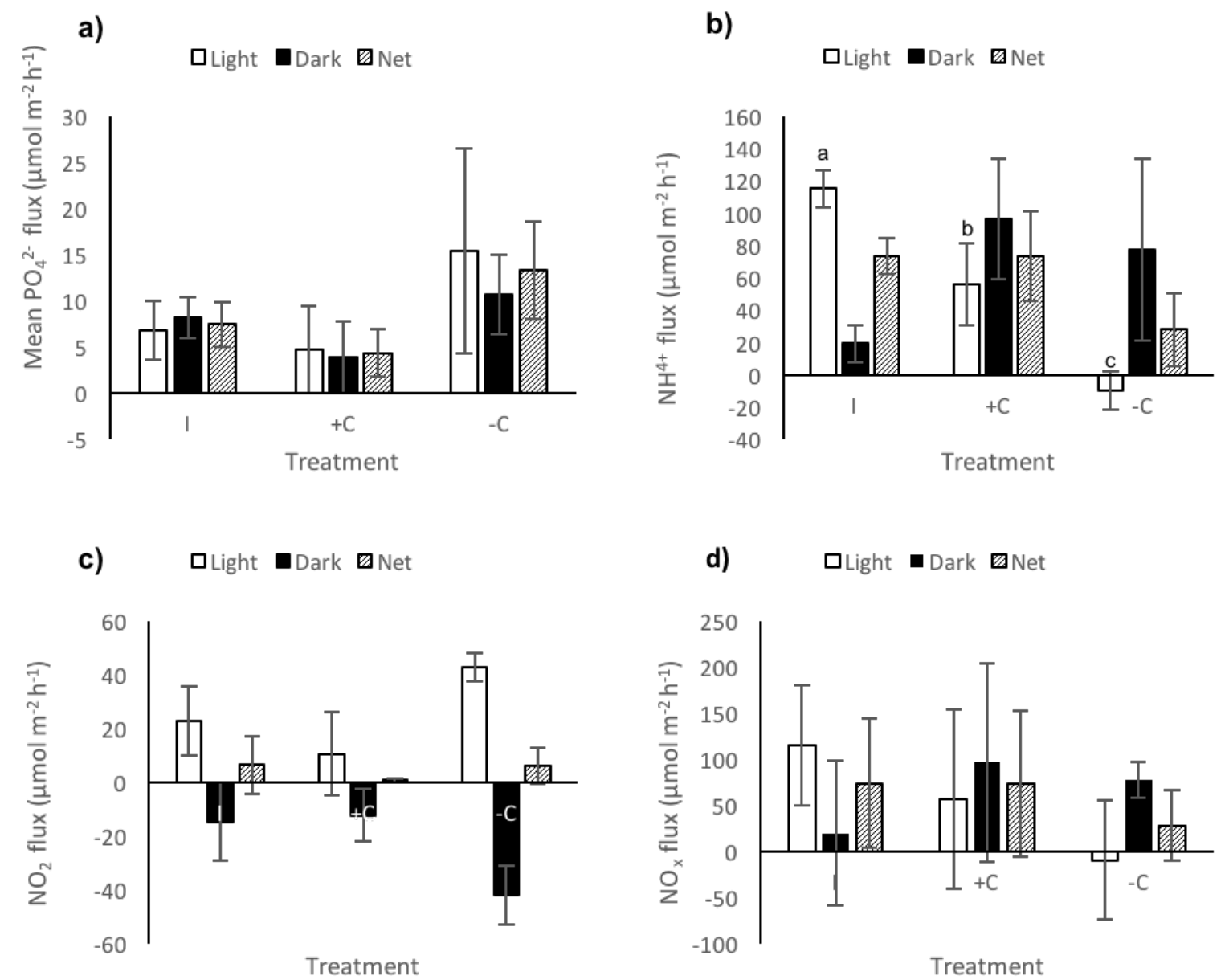
22 Fig. S3. Nitrogen metabolism pathway map 00910 downloaded from the Kyoto Encyclopaedia 23 for Genes and Genomes (KEGG) database. In the upper part of the diagram, the numbers in the 24 boxes are Enzyme Commission (EC numbers) for enzymes and the chemical reactions they 25 catalyse. In the lower part of the diagram, the enzyme numbers are replaced by the codes for 26 the gene that code for each enzyme. Arrows indicate the direction and pathway of the reactions: 27 arrows pointing to the right indicate reduction reactions and arrows pointing to the left indicate 28 oxidation reactions. The circles indicate the different inorganic forms of nitrogen.

29

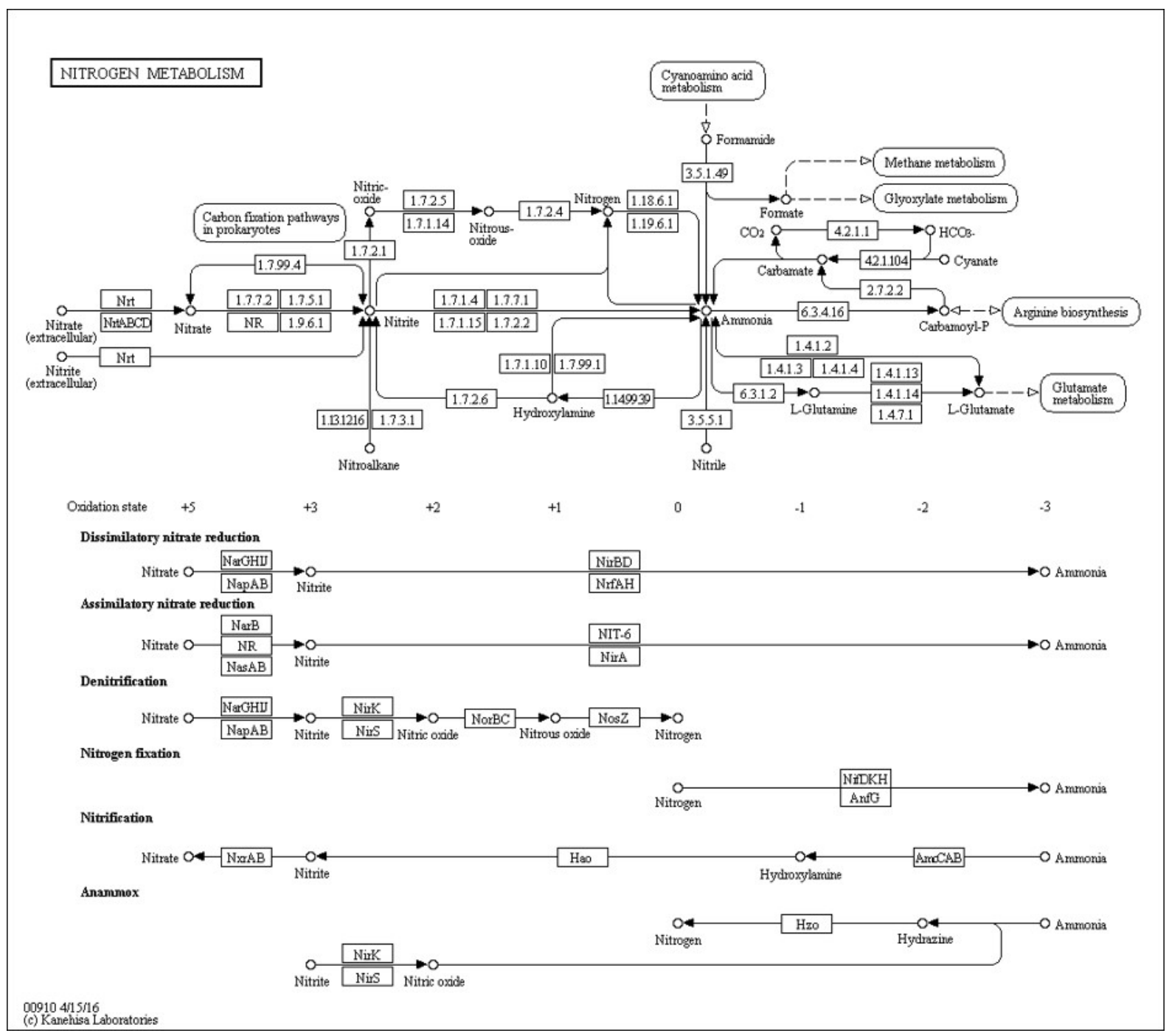

